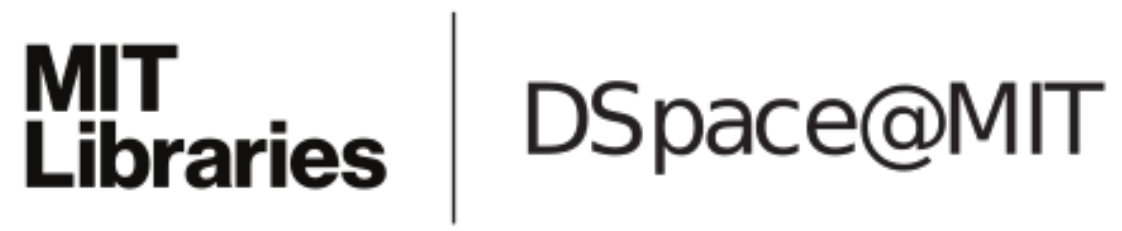

\author{
MIT Open Access Articles
}

Effects of mineral aerosols on the summertime climate of southwest Asia: Incorporating subgrid variability in a dust emission scheme

The MIT Faculty has made this article openly available. Please share how this access benefits you. Your story matters.

Citation: Marcella, M. P., and E. A. B. Eltahir. "Effects of Mineral Aerosols on the Summertime Climate of Southwest Asia: Incorporating Subgrid Variability in a Dust Emission Scheme." Journal of Geophysical Research 115.D18 (2010). Copyright 2010 by the American Geophysical Union.

As Published: http://dx.doi.org/10.1029/2010jd014036

Publisher: American Geophysical Union (AGU)

Persistent URL: http://hdl.handle.net/1721.1/77637

Version: Final published version: final published article, as it appeared in a journal, conference proceedings, or other formally published context

Terms of Use: Article is made available in accordance with the publisher's policy and may be subject to US copyright law. Please refer to the publisher's site for terms of use. 


\title{
Effects of mineral aerosols on the summertime climate of southwest Asia: Incorporating subgrid variability in a dust emission scheme
}

\author{
M. P. Marcella ${ }^{1}$ and E. A. B. Eltahir ${ }^{1}$ \\ Received 9 February 2010; revised 11 May 2010; accepted 24 May 2010; published 17 September 2010.
}

[1] Improvements in modeling mineral aerosols over southwest Asia are made to the dust scheme in a regional climate model by representing subgrid variability of both wind speed and surface roughness length. The new module quantifies wind variability by using model meteorology while assuming that wind speed follows a Gaussian distribution. More specifically, wind variability is approximated by dry convective eddies within the planetary boundary layer, forced by sensible heat fluxes at the surface. Incorporating subgrid variability of wind increases aerosol optical depth (AOD) over the region by nearly $35 \%$ while reducing incoming shortwave radiation by an additional $5-10 \mathrm{~W} / \mathrm{m}^{2}$. Likewise, the dust scheme is modified to include the variability of surface roughness length over southwest Asia. Here an empirical distribution of roughness length for each grid cell is calculated based on the USGS's $4 \mathrm{~km}$ resolution land cover data set. However, incorporating roughness length variability does not significantly alter dust emissions over the region due to the relatively homogeneous land cover conditions. Nevertheless, including spatial variability for wind results in aerosol optical depth values closer to observational data sets, particularly MISR, which performs better than MODIS over this region. However, RegCM3's dust model still underestimates AOD over southwest Asia. In addition to improvements made in RegCM3's dust model, this work examines the effects of mineral aerosols on the mean monthly, surface summertime climate of southwest Asia. It is shown that dust emissions reduce average summertime surface temperatures by approximately $0.5^{\circ} \mathrm{C}$ while attenuating shortwave incident radiation by nearly $25 \mathrm{~W} / \mathrm{m}^{2}$. Thus, the emission of dust is an important surface process in shaping the summertime climate over southwest Asia. However, both a warm bias in surface temperatures and overestimation of incoming shortwave radiation still exist in RegCM3 and need to be further addressed.

Citation: Marcella, M. P., and E. A. B. Eltahir (2010), Effects of mineral aerosols on the summertime climate of southwest Asia: Incorporating subgrid variability in a dust emission scheme, J. Geophys. Res., 115, D18203, doi:10.1029/2010JD014036.

\section{Introduction}

[2] Mineral aerosols, dust, are known to have important implications in shaping the global climate via effects on radiation and clouds, and thus temperature and precipitation [Miller and Tegen, 1998; Sokolik et al., 2001]. Yet, the role dust plays on regional climates has only recently been examined in the literature [Solmon et al., 2008; Zhang et al., 2009]. Although these models, both global and regional, perform satisfactorily in simulating dust episodes, many past studies have constrained dust emissions based on observations of dust loading [Cakmur et al., 2004]. Moreover, most models assume dust emissions, and the processes leading to

\footnotetext{
${ }^{1}$ Department of Civil and Environmental Engineering, Massachusetts Institute of Technology, Cambridge, Massachusetts, USA.

Copyright 2010 by the American Geophysical Union. 0148-0227/10/2010JD014036
}

such, occur at horizontal scales on the order of the model's grid cell resolution, which range, typically, from one half to two degrees. However, research, as well as observations, have shown that variability of surface meteorological variables, such as wind, may be important in accurately simulating dust emissions within global circulations models [Cakmur et al., 2004; Engelstaedter and Washington, 2007]. Here we develop similar schemes that quantify wind and roughness length variability at subgrid scales and implement them in a regional climate model's (RCM) dust emission scheme. As a result, this study provides some insight into how sensitive regional dust models are to the spatial variability of certain surface features.

[3] Furthermore, over southwest Asia, the summer months bring dust storms that dramatically impact the regional landscape as well as the lives of many of its inhabitants. Some work has shown that these dust events significantly affect the synoptic regimes over the Middle East causing heat lows to persist for longer time periods [Mohalfi et al., 1998]. This study, however, looks to 
examine the effects of dust emissions on southwest Asia's surface climate. This objective is first achieved by improving the performance of an RCM in simulating dust emissions over southwest Asia. With such a model, a more accurate examination of the impacts of dust emissions on the regional climate over southwest Asia can be completed.

\section{Model Description and Observational Data Sets}

\subsection{Regional Climate Model Version 3}

[4] In this study, Regional Climate Model version 3 ( $\operatorname{Reg} C M 3$ ) is used to simulate the summertime climate over the semiarid region of southwest Asia. Several studies have been completed using RegCM3, as referenced in the work of Giorgi et al. [1998]. Originally developed at the National Center for Atmospheric Research (NCAR) and now maintained at the International Center for Theoretical Physics (ICTP), RegCM3 is a three-dimensional, hydrostatic, compressible, primitive equation, $\sigma$ vertical coordinate, RCM. RegCM3 maintains much of the dynamical core of NCAR/ Pennsylvania State University's mesoscale model, MM5 [Grell et al., 1994]. The model now employs NCAR's Community Climate Model (CCM3) radiative transfer package [Kiehl et al., 1996]. In addition, land surface physics are modeled by the Biosphere-Atmosphere Transfer Scheme (BATS1e) of Dickinson et al. [1993], while boundary layer physics are modeled by Holtslag et al. [1990] nonlocal planetary boundary layer scheme [Giorgi et al., 1993a]. RegCM3 also employs Zeng's bulk aerodynamic ocean flux parameterization, where sea surface temperatures (SST's) are prescribed [Zeng et al., 1998]. In addition, three different convection schemes (Kuo, Grell, and Emanuel) are available for nonresolvable rainfall processes [Giorgi et al., 1993b]. After some experimentation with other convection schemes, the Kuo scheme best simulated the magnitude as well as spatial distribution of winter rainfall and thus was chosen for our experiments [Marcella and Eltahir, 2008]. Lastly, RegCM3 includes a large-scale, resolvable, nonconvective moisture scheme, the subgrid explicit moisture scheme SUBEX [Pal et al., 2000]. The authors refer readers to Pal et al. [2007] for the most recent developments and description of RegCM3.

\subsection{Desert Dust Module of Regional Climate Model Version 3}

[5] RegCM3 features a fully coupled aerosol chemistry model including a radiatively active dust module for semidesert and desert grid cells [Zakey et al., 2006]. In this study, we used an updated version of the Zakey et al. [2006] dust model. Dust emissions are strongly dependent on wind speed, surface characteristics, and soil particle size. Following the work of Marticorena and Bergametti [1995] and Alfaro and Gomes [2001], the dust emission calculation is based on empirical parameterizations for both soil aggregate saltation as well as sandblasting processes. Dust emissions within the scheme follow four basic steps, (1) based on a three-mode lognormal distribution determined by the soil texture class, the specification of soil aggregate size, $D_{p}$, distribution for each model grid cell followed by (2) the calculation of a minimum threshold friction velocity based on empirical parameterizations of Marticorena and Bergametti [1995] which leads to (3) the calculation of the horizontal saltating soil aggregate mass flux, $d H_{F}\left(D_{p}\right)$, defined as:

$$
d H_{F}\left(D_{p}\right)=E * \frac{\rho_{a}}{g} * u^{3} *\left(1+R\left(D_{p}\right)\right) *\left(1-R^{2}\left(D_{p}\right)\right) * d S_{r e l}\left(D_{p}\right)
$$

where, $E$ is the ratio of the erodible to total surface, $\rho_{a}$ is the density of air, $g$, gravity, $u^{*}$ is the wind friction velocity, $R\left(D_{p}\right)$ is the ratio of the minimum threshold friction velocity to the actual friction velocity and $d S_{r e l}\left(D_{p}\right)$ is the relative surface of soil aggregate of diameter $D_{p}$. Finally, (4) the calculation of the vertically transportable dust particle mass flux generated by the saltating aggregates is performed. Essentially, a portion of the horizontal saltation flux is proportioned to a kinetic energy flux and the vertical flux of the soil aggregates is determined via binding energies and this kinetic energy. From here, transport bins for different dust particle sizes are used for advection and deposition (both wet and dry) of dust particulates following the chemical tracer model in RegCM3. It should be noted that preferred dust sources based on topography or regions of easily erodible soils are not represented in this dust module. Essentially, these preferred sources, based on topographical depressions, reflect certain soil textures which are conducive to emissions. Hence, theoretically, these regions should be reflected in the soil texture map.

[6] Therefore, based on the highly nonlinear dependence of equation (1) on wind friction velocity, wind speeds, to a large degree, determine dust emissions in the module. Additionally, surface roughness lengths help determine not only the friction velocity but also provide a correction factor for the minimum threshold velocity based on the formulation of Marticorena and Bergametti [1995]. Thus, accounting for subgrid variability of both wind speeds and roughness lengths may significantly affect emissions in the dust module of RegCM3.

\subsection{University of Delaware (Willmott and Matsuura) V2.02 Global Air Temperature Data Set}

[7] The Willmott and Matsuura high-resolution gridded data set (V2.02) hereafter referenced as UDEL, consists of a monthly time series of global surface air temperature covering the period 1900 to 2002. Surface temperature measurements from available station data are interpolated onto a global $0.5^{\circ} \times 0.5^{\circ}$ resolution grid [Legates and Willmott, 1990]. The UDEL temperature data available for the years of 2000-2004 are used in this study. It is important to note that due to the lack of station data in this region, some smoothing may occur in UDEL estimates for temperature. The exact construction and description of the interpolation scheme used for each variable can be found in the work of Willmott and Matsuura [1995].

\subsection{NASA's Moderate Resolution Imaging Spectroradiometer and Multiple-Angle Imaging Spectroradiometer}

[8] Launched onboard NASA's Terra satellite Earth Observing System (EOS) mission in late 1999, the Moderate 
Resolution Imaging Spectroradiometer (MODIS) exploits a multispectral retrieval algorithm strategy to estimate aerosol optical depth (AOD) over both land and water. Here, level 3 MODIS global Aerosol Optical Depth (AOD) product, averaged monthly, at $1.0^{\circ} \times 1.0^{\circ}$ gridded resolution data, centered at $550 \mathrm{~nm}$, is used to compare to model simulations of AOD. Summertime MODIS data from the years 2000 through 2004 are used in this analysis. A more detailed description of the retrieval and measurement of MODIS values can be found in the work of Kaufman et al. [1997].

[9] Similarly launched on NASA's Terra satellite EOS mission, the Multiangle Imaging Spectroradiometer (MISR) is also used to compare model simulations of aerosol optical depth values. Rather than measuring at multibands, as MODIS does, MISR contains nine cameras that observe the Earth at nine different viewing angles. In this study, MISR Level 3 Component Global Aerosol Product, at $0.5^{\circ} \times 0.5^{\circ}$ resolution, is used for AOD values at $555 \mathrm{~nm}$. The temporal coverage used in this analysis follows that of MODIS, from 2000 to 2004. For further information on the MISR data set, the authors refer the reader to Martonchik et al. [1998].

\subsection{NASA-Langley Research Center Surface Radiation Budget}

[10] In order to assess the performance of RegCM3 in simulating incoming surface solar radiation, NASALangley's Surface Radiation Budget (NASA-SRB) is compared to RegCM3 values of incident shortwave radiation. NASA's SRB data is based on International Satellite Cloud Climatology Project (ISCCP) products as well as meteorological data from the Global Modeling and Assimilation Office's (GMAO) reanalysis data sets. Using radiative transfer algorithms, the NASA-SRB data set provides both surface shortwave and longwave radiation on a monthly averaged, global grid [Darnell et al., 1996; Gupta et al., 1999]. In this study, summertime values of surface shortwave incident from July 2000 through August 2004 are compared to model output. It is important to note that the SRB estimates are reanalysis, modeled, data where root square mean errors are around $25 \mathrm{~W} / \mathrm{m}^{2}$ when compared to ground-measured fluxes. Lastly, NASA-SRB data during this time period are available at $1^{\circ} \times 1^{\circ}$ resolution.

\section{Subgrid Variability Schemes}

\subsection{Wind Variability}

[11] Since the dust emissions scheme is driven by resolvable winds given at the resolution of RegCM3's land surface grid cell, "gustiness" that may occur at the subgrid scale is not accounted for currently within the dust model. Following the work of Cakmur et al. [2004], we assume surface wind speeds follow a Gaussian distribution which can be described with a mean value (grid cell resolved), $\mu$, and a standard deviation, $\sigma$. Research has shown that strong surface solar heating can result in dry convection that mixes dust up from the surface layer to the atmosphere [Schulz et al., 1998]. Here we assume that wind speed variability, or $\sigma$, within a grid cell, is driven by these dry convective eddies, the dry convective velocity scale [Miller et al., 1992; Lunt and Valdes, 2002; Cakmur et al., 2004]. Thus, the dry convective scale, $w_{d}$, strongly dependent on the kinematic heat flux within the boundary layer, can be written as:

$$
w_{d}=\left(\frac{Q_{h} g H}{\rho_{a} C_{p} T_{a}}\right)^{1 / 3}=\sigma
$$

where, $Q_{h}$ is the surface sensible heat flux, $H$, the boundary layer height, $g$, gravity, $\rho_{a}$ the density of air, $T_{a}$, surface temperature and $C_{p}$, the specific heat at constant pressure. Previous work has concluded that these dry convective eddies represent reasonably well the horizontal fluctuations in wind speeds at the surface [Deardorff, 1974; Willis and Deardorff, 1974; Wyngaard, 1985].Given values for $\mu$ and $\sigma$, we then calculate the $95 \%$ range for wind values, $w$, as follows:

$$
\left(w_{1}=\mu-(2 * \sigma)\right)<w<\left(\mu+(2 * \sigma)=w_{10}\right)
$$

where the number of bins, $b$, is user-defined and set to 10 for computational efficiency in our simulations. Given the bounds, a distribution for wind speed is constructed by linearly incrementing wind bin values, $w_{b}$, from $w_{1}$ up to $w_{10}$. From here, the corresponding probability for each $w_{b}$ is calculated:

$$
p\left(w_{b}\right)=\left(\frac{1}{\sigma \sqrt{2 \pi}}\right) \exp \left(-\frac{\left(w_{b}-\mu\right)^{2}}{2 \sigma^{2}}\right) * \frac{\left(w_{10}-w_{1}\right)}{9}
$$

The dust module then performs all calculations involving wind speeds for each $w_{b}$ value. These computations essentially amount to a distribution for the wind friction velocity, $u^{*}$. Finally, the total dust emissions, FDP, is integrated overall wind speed bin values with their corresponding probability:

$$
F D P=\sum_{b=1}^{10} p\left(w_{b}\right) * f\left(w_{b}\right)
$$

where, $f\left(w_{b}\right)$ represents dust emissions for a given wind bin value and $p\left(w_{b}\right)$ being the corresponding probability of that $w_{b}$ given a normal distribution with model calculated $\mu$ and $\sigma$. Figure 1 shows a schematic of the new subgrid wind variability module.

\subsection{Roughness Length Variability}

[12] In addition to accounting for variability of wind speed at the subgrid level, the dust module is also improved by including the variability of vegetation cover, namely via surface roughness lengths. Within RegCM3, roughness length values are assigned based on vegetation type, which is derived from the U.S. Geological Survey's (USGS) Global Land Cover Characterization (GLCC) data set [USGS, 1997]. Since vegetation cover varies over scales significantly smaller than the typical regional climate model horizontal resolution (i.e., 30 kilometer as used in this study), including the variability of land cover may affect dust emissions.

[13] Here we introduce an empirical distribution for land cover and hence roughness length values for each grid cell based on the USGS's GLCC 4 kilometer resolution data set. In this scheme, each RegCM3 grid cell contains a percent- 


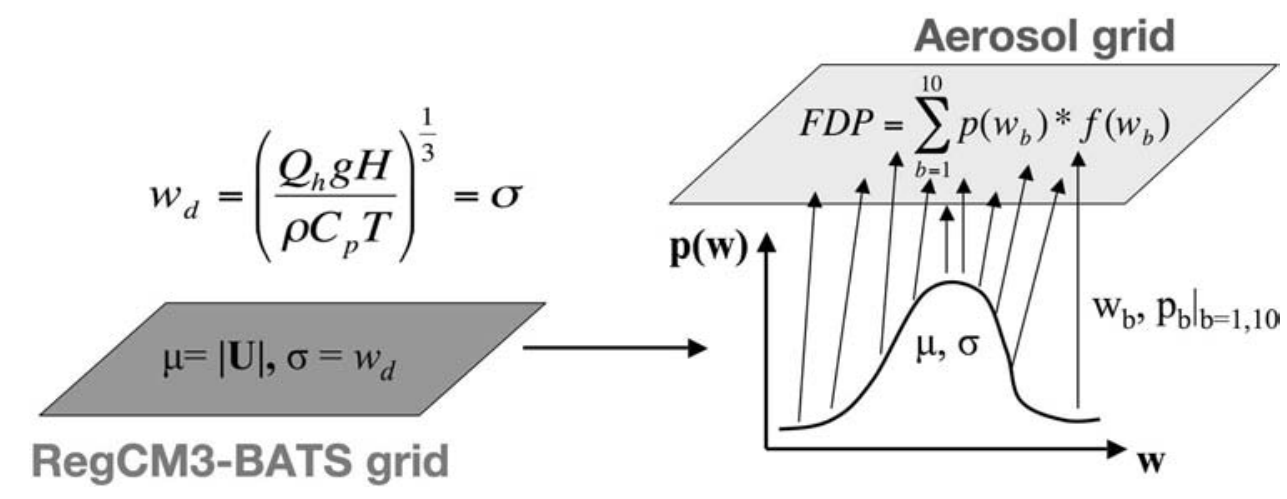

Figure 1. Schematic illustrating how subgrid wind variability is implemented within the dust module of RegCM3. The authors refer the readers to the text for definitions of all symbols.

age covered by all fifteen land covers based on the vegetation types present in the four kilometer USGS GLCC grid cells that corresponds to the RegCM3 grid cell (see Figure 2). From here, all calculations in the dust model are performed with the given specified roughness length values of each land cover type. These calculations essentially result in new values for both wind threshold velocity and wind friction velocity. Once completed, dust emissions for a given land cover, $i, F D P_{i}$, are multiplied by the percent of the grid cell

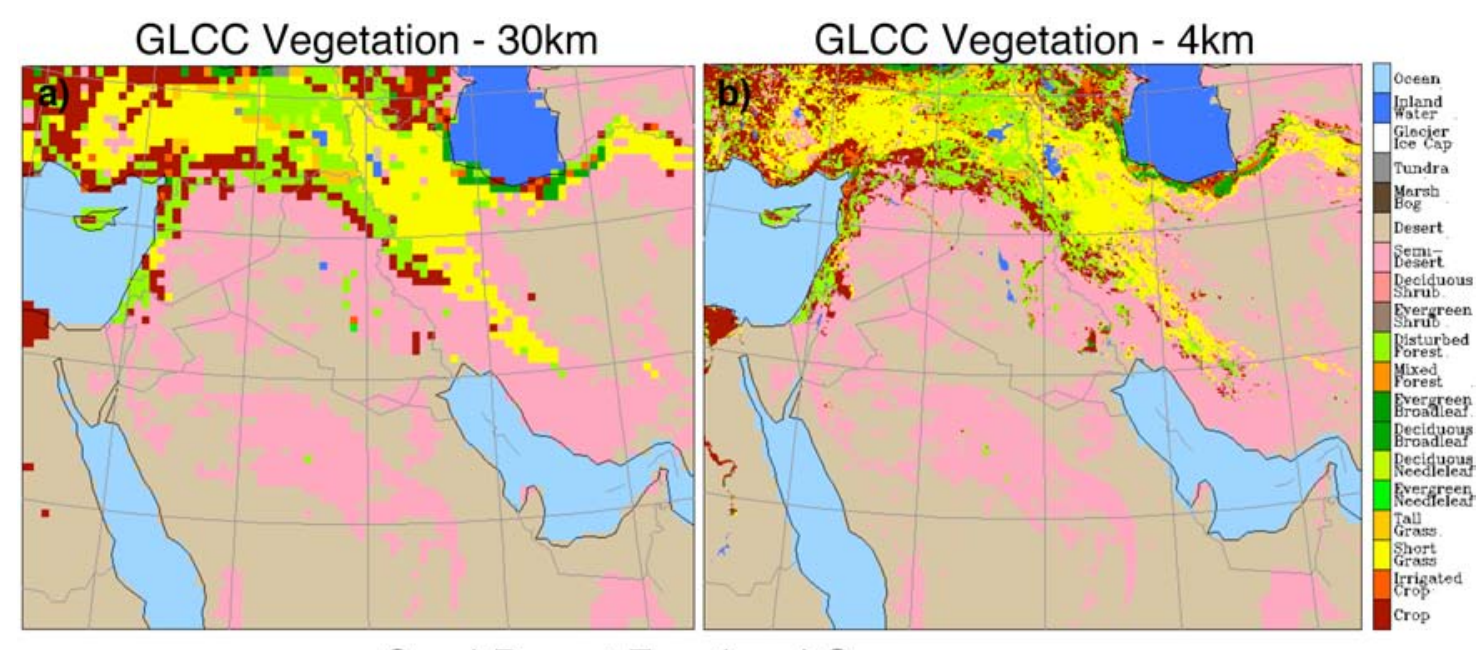

\section{Semi-Desert Fractional Coverage}

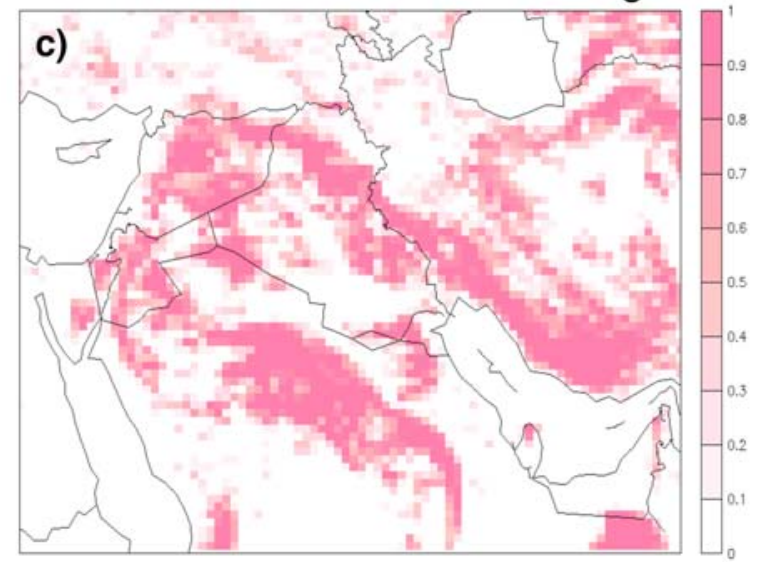

Figure 2. Vegetation types of (a) RegCM3 simulation at $30 \mathrm{~km}$ resolution and (b) USGS GLCC data set at $4 \mathrm{~km}$ resolution. (c) The resulting fraction of each $30 \mathrm{~km}$ grid cell in RegCM3 simulation covered with semidesert based on USGS GLCC $4 \mathrm{~km}$ data is an example of the grids used for the empirical distribution in the subgrid roughness length variability. 


\section{Domain Topography \& Vegetation}

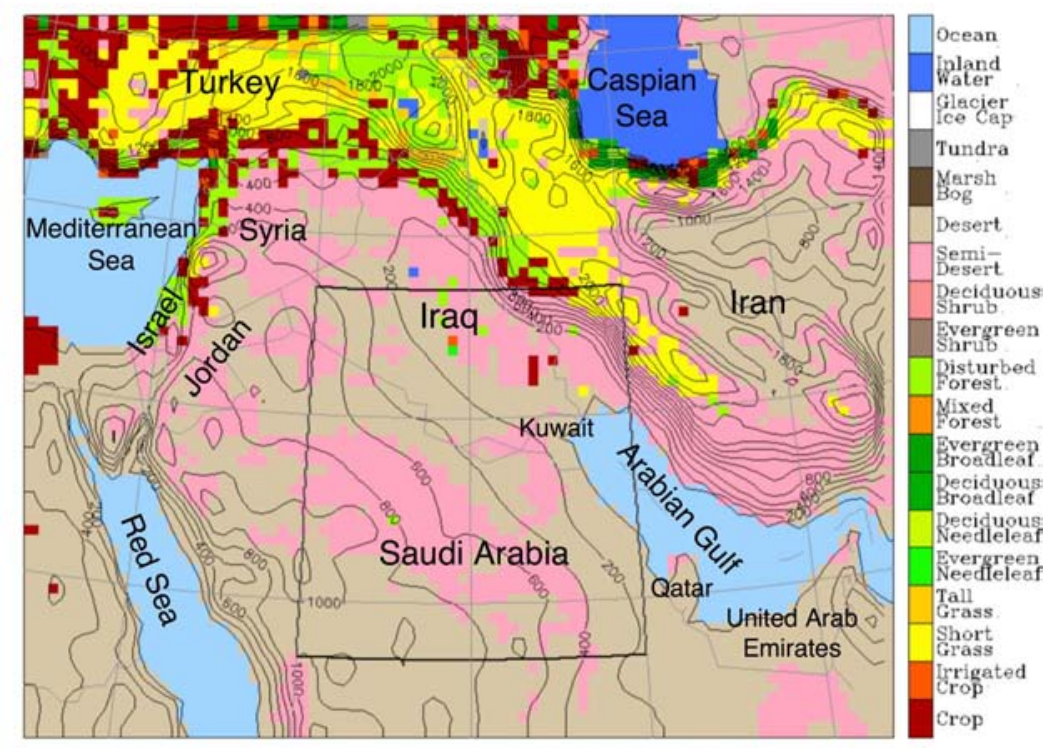

$\mathrm{NX}=88 \mathrm{NY}=74 \mathrm{ds}=30 \mathrm{~km} \quad \mathrm{CLAT}=31 \mathrm{CLON}=44.5$ Lambert

Figure 3. Domain implemented for all simulations with topography contoured ( $200 \mathrm{~m}$ intervals) and vegetation shaded. A significant portion of the domain is classified by semidesert or desert land cover at $30 \mathrm{~km}$.

covered with said land cover $i$, pcent $_{i}$. The following formulation results:

$$
\begin{aligned}
F D P= & \sum_{i=1}^{15}\left(\text { pcent }_{s d} * F D P_{s d}\right)+\left(\text { pcent }_{\text {des }} * F D P_{\text {des }}\right) \\
& +\left(\text { pcent }_{i} * F D P_{i}\right)+\ldots
\end{aligned}
$$

where, the subscripts $s d$ and des are semidesert and desert land cover, respectively. It is important to note that although the dust scheme is only activated for grid cells designated as desert or semidesert at 30 kilometers, it is possible for these cells to have a percentage of their total land cover type not composed of semidesert or desert at the finer 4 kilometer resolution.

\section{Experimental Design}

\subsection{Domain Setup}

[14] Simulations using RegCM3 were completed spanning the period from 2000 to 2004 . The domain, centered at $31^{\circ} \mathrm{N}, 44.5^{\circ} \mathrm{E}$ at $30 \mathrm{~km}$ resolution, has 88 points in the zonal and 74 points in the meridional direction using a Lambert Conformal projection. The domain covers most of southwest Asia from the Mediterranean and Caspian Seas in the north to the Red Sea and Oman in the south. Figure 3 represents the model domain as well as topography and land use in all simulations. As examples of two different scales, areal averages are calculated over Kuwait $\left(46.5^{\circ} \mathrm{E}-\right.$ $\left.48.5^{\circ} \mathrm{E}, 28.4^{\circ} \mathrm{N}-30.2^{\circ} \mathrm{N}\right)$ and a boxed region $\left(23.5^{\circ} \mathrm{E}-\right.$ $33.5^{\circ} \mathrm{E}, 40^{\circ} \mathrm{N}-50^{\circ} \mathrm{N}$ ) in Figure 3 . Initial and boundary conditions are implemented from the National Center for Environmental Prediction/National Center for Atmospheric Research (NCEP/NCAR) Reanalysis Project 2 (NNRP2) of
Kalnay et al. [1996]. Lateral boundary conditions (LBC's) were enforced by applying the exponential relaxation of Davies and Turner [1977]. To account for the effects of boundary conditions, six points (approximately 2 degrees) across the lateral boundaries are stripped from model results presented. As mentioned prior, SST's are prescribed to RegCM3 from the National Oceanic and Atmospheric Administration (NOAA) optimally interpolated SST (OISST) data set of Reynolds [2002]. The SST data sets are $1^{\circ} \times 1^{\circ}$ monthly resolution and are based on in situ and satellite observations.

\subsection{Simulations Description}

[15] A total of four different RegCM3 simulations are performed with varying configurations of the model. The control simulation, CONT, provides a baseline simulation using the components of the model listed above but without RegCM3's aerosol model. DUST contains the same setup as CONT but includes the current, standard dust model in RegCM3. WIND improves on the dust model by including the scheme for subgrid wind variability, while ROU includes variability of roughness length at the subgrid scale. To discern the effects of wind and roughness variability on dust emissions, initial comparisons are made between DUST and WIND/ROU simulations. Then, to identify the impacts of dust on the regional climate of southwest Asia, CONT is compared to WIND. Table 1 provides a complete summary of simulations performed.

\section{Results and Discussion}

\subsection{Aerosol Optical Depth and the Effects of Subgrid Variability}

[16] Using estimates from both MODIS and MISR data, a short-term climatology of dust loading over southwest Asia 
Table 1. Summary of Simulations Performed for the Period of $2000-2004^{\mathrm{a}}$

\begin{tabular}{lc}
\hline Simulation & $\begin{array}{c}\text { Description of } \\
\text { Processes Included }\end{array}$ \\
\hline CONT & - \\
DUST & dust module of Zakey et al. [2006] included \\
ROU & dust module with subgrid variability of wind included \\
dust module with subgrid variability \\
of roughness length included
\end{tabular}

${ }^{a}$ All simulations use NNRP2 lateral boundary conditions and OISST prescribed sea surface temperatures. These names will be used to reference each simulation in the text.

is constructed. Shown in Figure 4 are the average annual daily AOD values over southwest Asia for MODIS, MISR, and RegCM3's DUST simulation. Both satellite data sets show local maxima in aerosols over the Mesopotamian Valley of Iraq and central Iran, south of the Caspian Sea. More specifically, in the MODIS data set, one can clearly see locally high dust loading over central Iraq where values range from 0.50 to 0.70 (Figure 4a). Similarly, in the MISR data set, a distinct positive gradient in AOD occurs when moving from the Syrian Desert in the north, to the Arabian

\section{MODIS Annual Monthly AOD}

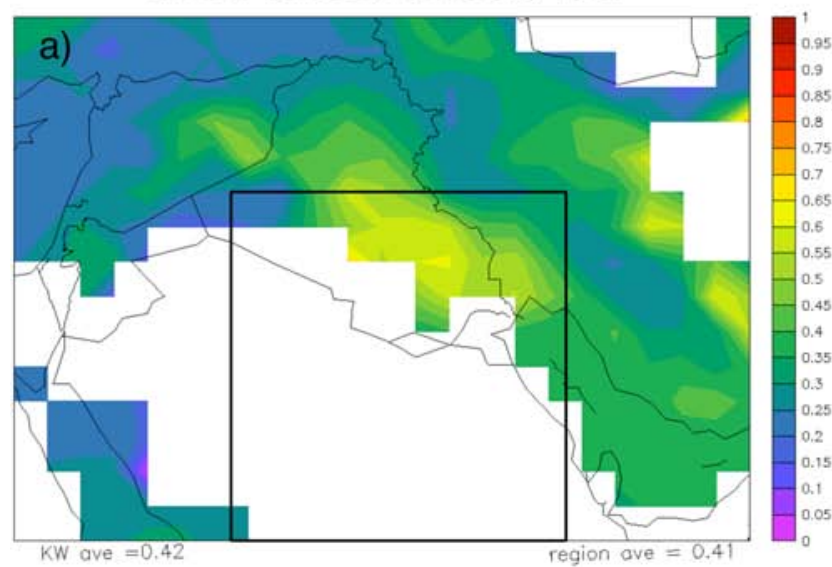

Peninsula further south (Figure 4b). Consequently, the spatial correlation between the two data sets is quite high with values ranging from 0.6 to 0.9 over most of the domain (not shown). Noticeable, however, in the MODIS estimates is the overall larger retrieval values across the domain (AOD values of 0.41 versus 0.31 in MISR). This bias has been well documented in the literature; Abdou et al. [2005] found that MODIS AOD estimates over land can be nearly 35\% larger than those of MISR. The differences are attributed to MODIS's inability to properly detect surface reflectance over bright surfaces such as deserts. As a result, this shortcoming also explains the lack of AOD values in MODIS estimates (white regions in Figure 4a) over the entire desert of the Arabian Peninsula.

[17] Comparisons of MODIS and MISR estimates of annual mean daily AOD to RegCM3 simulations reveal a significant underestimation in AOD by the model. As shown in Figure 4, AOD observations over the region $(0.31-0.41)$ are significantly higher than RegCM3 simulated values which are closer to 0.15 ; as a result, $\mathrm{RegCM} 3$ underpredicts observations by a factor of two over southwest Asia. Spatially, RegCM3 performs well in simulating an increase in AOD values from the north (Turkey) to the south (Saudi Arabia), including the locally dusty areas east and south of

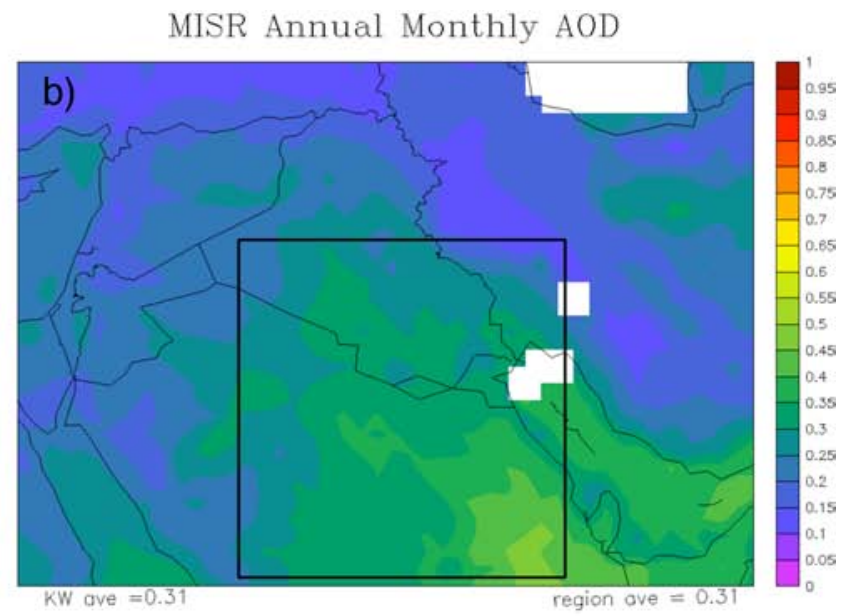

DUST Annual Monthly AOD

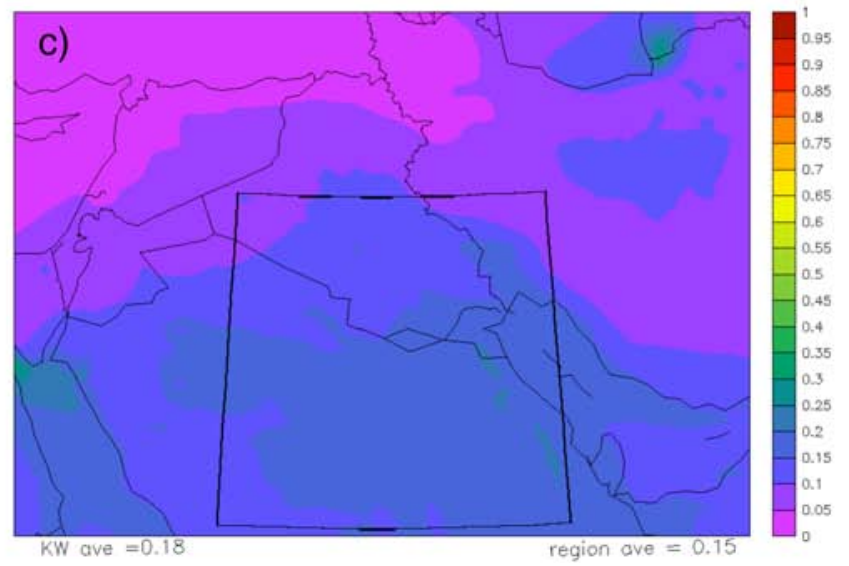

Figure 4. Average annual daily aerosol optical depth (AOD) as estimated by (a) MODIS, (b) MISR, and (c) RegCM3 DUST simulation from 2000 to 2004. Note that areal averages over both Kuwait and boxed region are also shown. White grid boxes are regions where satellite data is unavailable. 

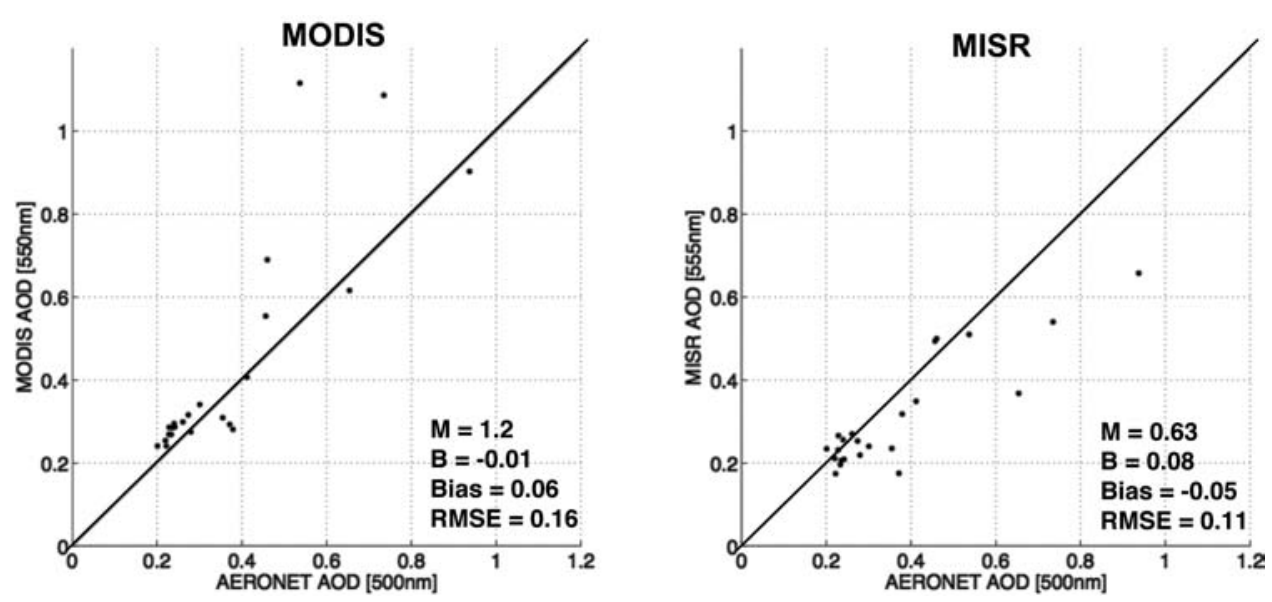

Figure 5. Scatter of MODIS and MISR AOD values against AERONET measurements over Karachi, Kuwait City, Nes Ziona, and Bahrain. Also shown are slope (M) and $y$ intercept (B) of the best fit line as well as the bias and root mean square error (RMSE).

the Caspian Sea, which are similarly seen in MODIS and MISR (compare Figures $4 \mathrm{a}$ and $4 \mathrm{~b}-4 \mathrm{c}$ ). However, in all of these areas, RegCM3 values are significantly lower. Some of this underestimation in AOD values may be a result of large differences in sampling time/sizes between RegCM3 and MODIS/MISR. Where RegCM3 dust output is calculated every $3 \mathrm{~h}$, MODIS and MISR retrievals occur once a day or once every other day. Therefore, it is possible that some of the discrepancy may come from a rather coarse sampling size by the two satellites. Nevertheless, visible in the MODIS/MISR data, and well documented in the literature [e.g., Prospero et al., 2002; Engelstaedter and Washington, 2007] the dust source of central Iraq is not properly initiated in RegCM3. Consequently, AOD values in this region and further south are largely underestimated. It is suggested that the inclusion of subgrid variability in surface properties, such as gustiness and land cover, may help increase emissions over this area [Engelstaedter and Washington, 2007]. Similarly, assuming no dust emissions at the boundary may lead to underestimations in AOD caused by overestimation of advection of dust out of the boundary. Current work being completed shows that this process is important and that boundary conditions for dust concentrations impact AOD values and dust concentrations across the domain.

[18] Given the disparity between MODIS and MISR values over southwest Asia, we compare both retrievals to ground observations from the Aerosol Robotic Network (AERONET) in four desert sites over southwest Asia, including Karachi, Pakistan; Nes Ziona, Israel; Kuwait City, Kuwait; and Bahrain. AERONET stations use ground-based measurements from Sun photometers that measure AOD values across the globe [Holben et al., 1998]. At lower AOD values $(>0.40)$, both MODIS and MISR retrievals do well compared to AERONET estimates. However at higher values, MODIS overestimates values $57 \%$ of time whereas MISR underestimates about $42 \%$ of this time (see Figure 5). In any event, similar to Prasad and Singh [2006] and Abdou et al. [2005], we find that MISR performs better than MODIS in estimating the mean as well as variability of dust emissions with a lower bias and root mean square error (Figure 5). Moreover, Martonchik et al. [2004], finds that
MISR adequately retrieves AOD over bright surfaces such as desert regions. Therefore, when comparing model results to observations, we place more confidence in MISR's estimates of AOD.

\subsubsection{Wind Variability}

[19] The effects of including subgrid wind variability are highlighted in Figure 6 which shows summertime AOD values in RegCM3 DUST, ROU, and WIND simulations. Looking at Figure 6a, RegCM3's predicted summertime (JJA) AOD, the two main emission sites simulated by the model are clearly seen over Iraq's southern borders with Iran and Kuwait. Here, local AOD values are in the range of $0.20-0.30$ with plumes stretching southeasterly highlighting the common northwesterly winds which occur over the region, the shamals. As seen when comparing Figure 6a to Figure $6 \mathrm{c}$, including wind variability significantly increases AOD values over most of the region, particularly over the emission sites already present in southern Iraq and Kuwait and the plumes down the Gulf Coast. In these regions, aerosol optical depth increases by more than 0.05 with Kuwait's AOD up to 0.26 and the regional average 0.23 (see Table 2). Moreover, the plumes stretching down the coast of the Arabian Gulf experience large increases, on the order of 0.10 in dust loading (see Figure 6d). This result is expected as the emissions are a function of the third power of total winds, which now include the mean and the fluctuation or gustiness. Therefore, gusts (above the average wind value) dominate and cause a significant increase in emissions. In fact, emission rates for all four dust tracer bin sizes do increase between 30 and $35 \%$. As a result, including wind variability yields an approximately $35 \%$ increase in AOD values across the region. Likewise, the WIND simulation exhibits increased emissions over central Iraq which are absent in DUST. Yet, including wind variability makes a less pronounced difference across the Caspian Sea region. Given that variability (the standard deviation) is quantified by the kinematic heat flux (i.e., sensible heat, temperature, and boundary layer growth) this result is logical across the relatively cooler lands of northern Iran.

[20] Nevertheless, dust emissions over the Mesopotamian Valley are still smaller than observations and might be 
DUST JJA AOD

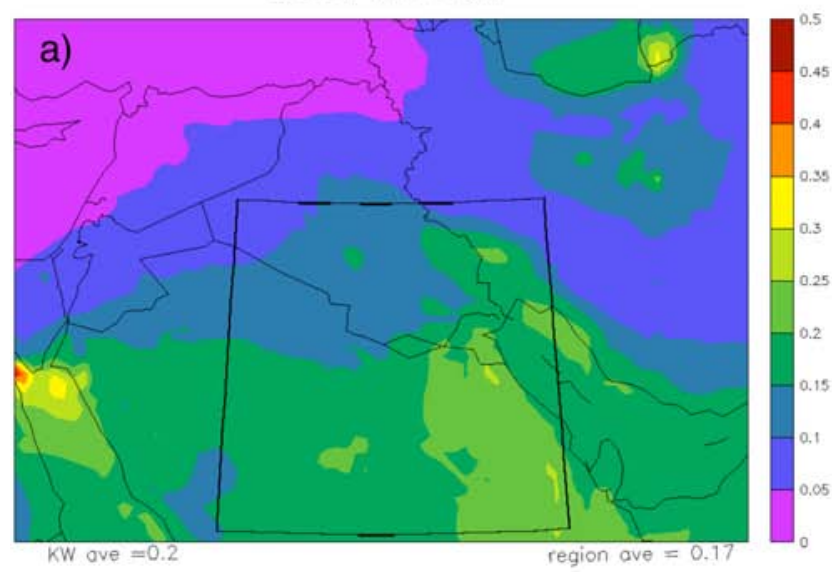

WIND JJA AOD

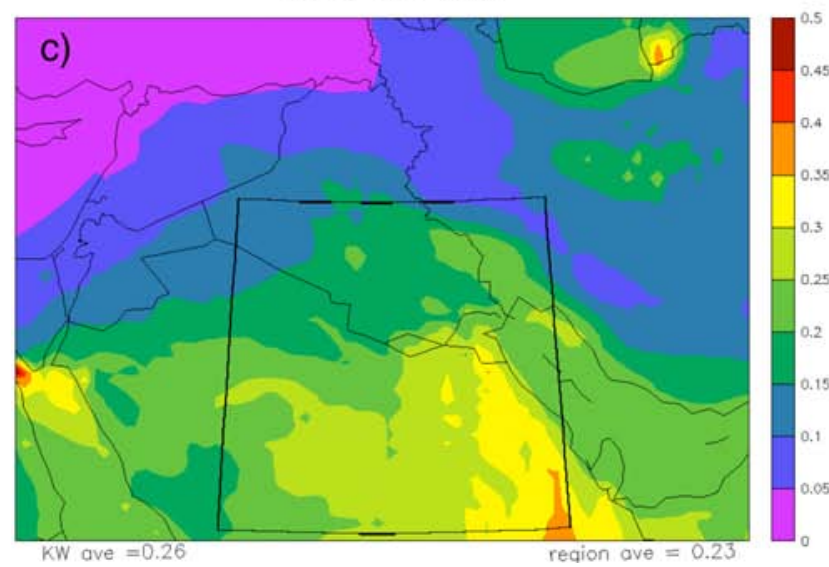

ROU JJA AOD

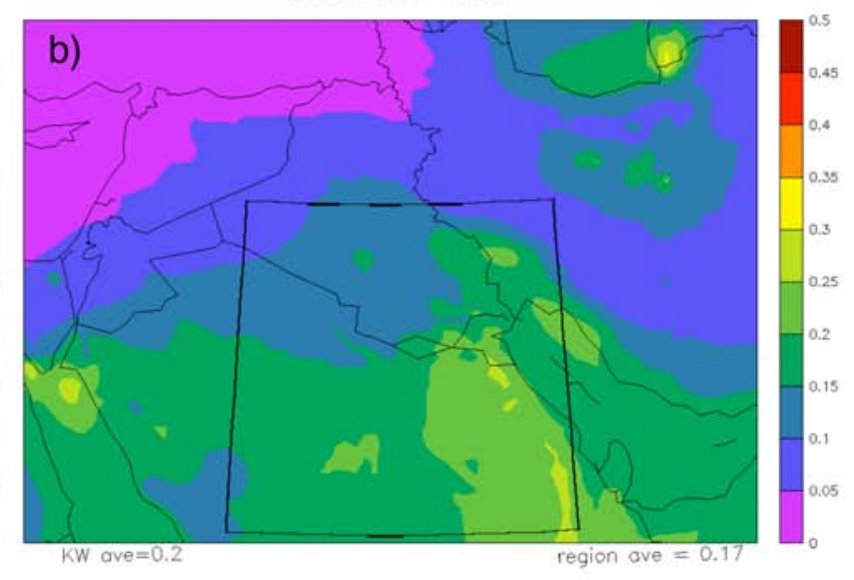

WIND-DUST JJA AOD

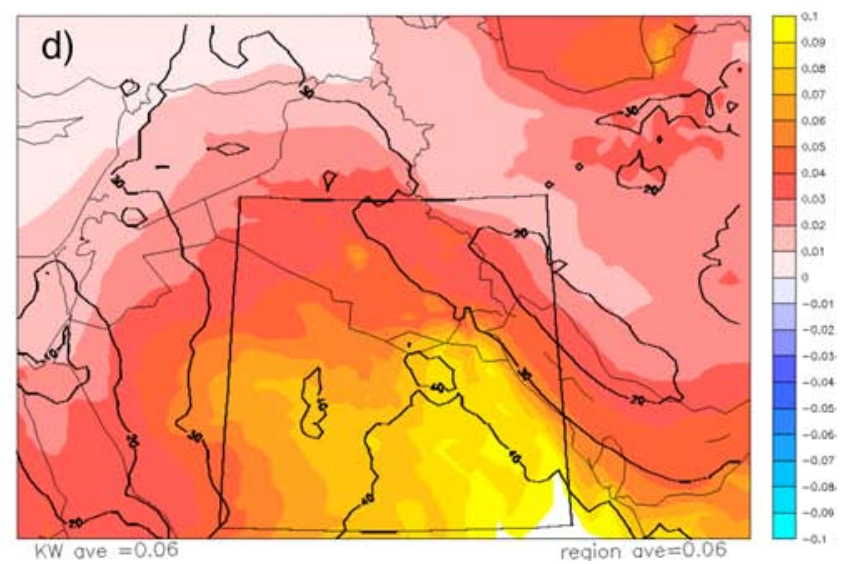

Figure 6. RegCM3 simulated average daily summertime (JJA) AOD in (a) DUST, (b) ROU, (c) WIND, and (d) WIND-DUST simulations for the period of 2000-2004. Also contoured in Figure 6d are the percentage differences in WIND-DUST AOD. Note that areal averages over both Kuwait and boxed region are also shown.

attributed to soil types or soil aggregate size distributions specified in the model across central and northern Iraq. For example, soils in RegCM3 are at thirty kilometer resolution where actual emissions can occur at scales significantly smaller. To this point, in this region, RegCM3 assumes a large, mostly clay area; the lack of sandy soils may reduce potential saltation and eventually dust emissions over the Mesopotamian Valley. To this point, it is important to note that soil texture types over this region are not well known. Therefore, it is instead possible that variability or error in the dust model may arise from the formulation of soil aggregate size distributions, not soil texture itself. For example, the work of Laruent et al. [2008] use a markedly different distribution for soil aggregate sizes. As a result, it is possible that given a certain texture class, a specific aggregate mode may not breach (or breach minimally) the threshold friction velocity resulting in no or small dust emissions. Further work should be performed in examining the sensitivity of the dust module to soil aggregate distributions. Additionally, as mentioned prior, large differences in sampling times between MISR and RegCM3 may also contribute to the AOD bias.

Table 2. Summary of Average Monthly AOD Values for Summertime (JJA) in MISR and RegCM3 Simulations DUST, ROU, and WIND ${ }^{\mathrm{a}}$

\begin{tabular}{ccc}
\hline $\begin{array}{c}\text { Observation/Simulation } \\
(\mathrm{JJA} A O D)\end{array}$ & $\begin{array}{c}\text { Kuwait } \\
\left(46.5^{\circ} \mathrm{E}-48.5^{\circ} \mathrm{E}, 28.4^{\circ} \mathrm{N}-30.2^{\circ} \mathrm{N}\right)\end{array}$ & $\begin{array}{c}\text { Region } \\
\left(40^{\circ} \mathrm{E}-50^{\circ} \mathrm{E}, 23.5^{\circ} \mathrm{N}-33.5^{\circ} \mathrm{N}\right)\end{array}$ \\
\hline MISR & 0.35 & 0.37 \\
DUST & 0.20 & 0.17 \\
ROU & 0.20 & 0.17 \\
WIND & 0.26 & 0.23 \\
\hline
\end{tabular}

\footnotetext{
${ }^{\mathrm{a}}$ Note that values are shown for the areal averages over Kuwait and the boxed region.
} 
MISR JJA AOD

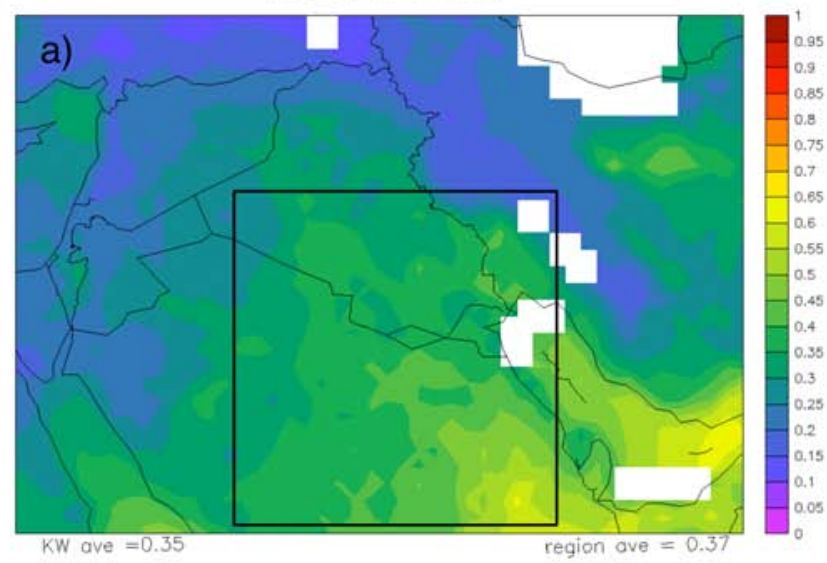

ROU JJA AOD

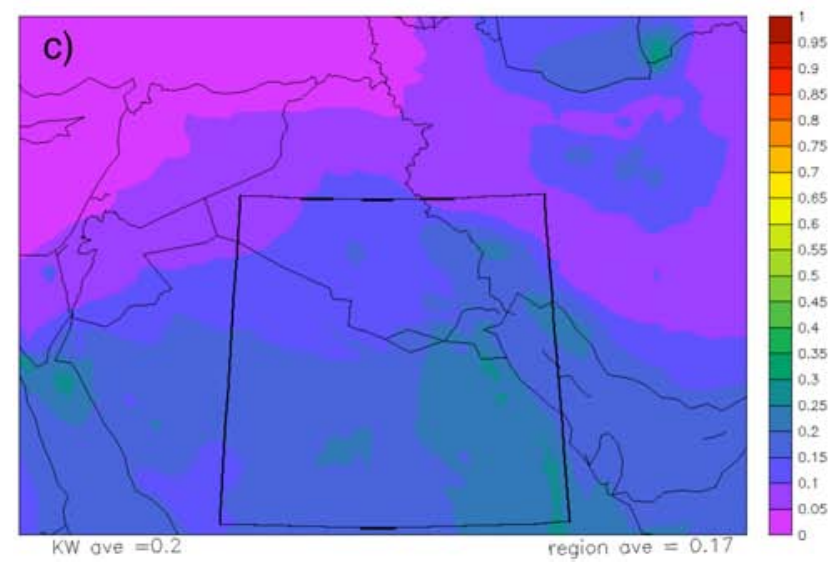

DUST JJA AOD

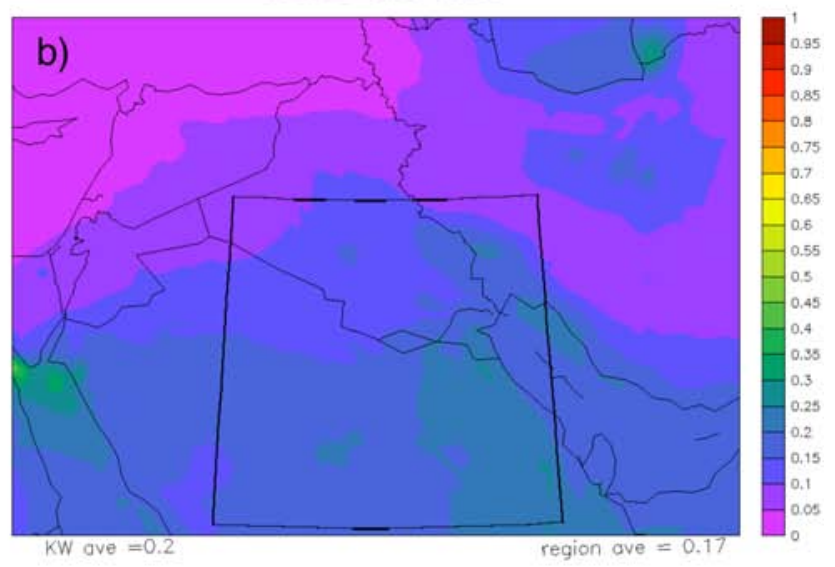

WIND JJA AOD

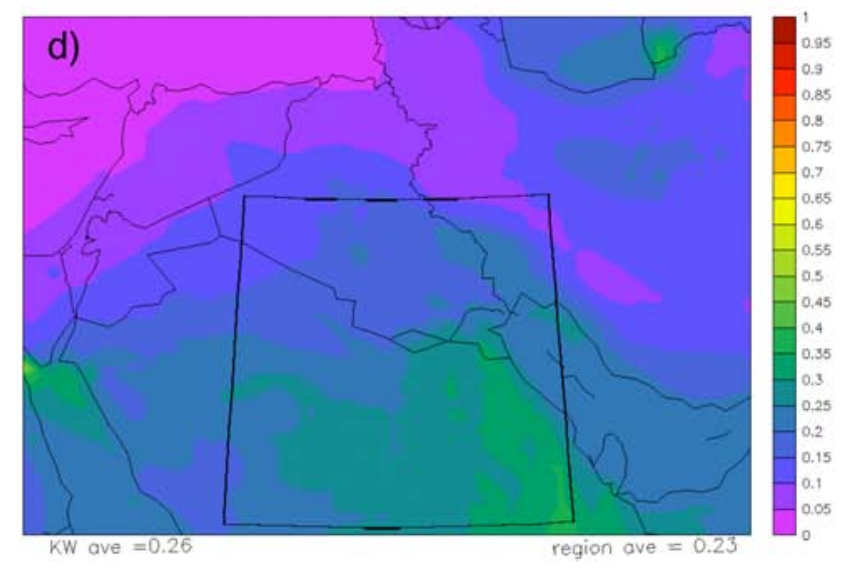

Figure 7. RegCM3 simulated average summertime (JJA) aerosol optical depth (AOD) in (a) MISR, (b) DUST, (c) ROU, and (d) WIND simulations for the period of 2000-2004. Note that areal averages over both Kuwait and boxed region are also shown.

\subsubsection{Roughness Length Variability}

[21] Unlike the effects from wind variability, including an empirical distribution for roughness length values does not remarkably affect dust emissions over the domain (compare Figures $6 \mathrm{a}$ to $6 \mathrm{~b}$ ). Simulated values of AOD remain the same across Kuwait and the boxed region as in the DUST simulation ( 0.2 and 0.17 , respectively). Insignificant differences are most likely due to the homogenous land cover over the region (see Figure 2). That is, most areas of active dust emissions are completely covered in semidesert or desert land cover, therefore little variability in surface roughness lengths is introduced. Likewise, assigned BATS values of roughness length for desert and semidesert are 5 and 10 centimeters, respectively, and are the dominant land types even at the finer $(4 \mathrm{~km})$ resolution; hence, with a small difference in values to begin with, little change is expected. In addition, given that the dust module is only activated over grid cells designated at the model resolution as desert or semidesert, further muting of potential variability occurs. It is important to note that experiments varying the dust model's roughness values revealed a strong sensitivity of the module to roughness length. As a result, this roughness length variability scheme would more likely effect dust emissions over regions such as West Africa where land cover varies widely throughout the Saharan Desert and Sahel region. Lastly, simulations including both wind and roughness variability were completed, but results were similar to WIND simulation. Additionally, simulations with both variability schemes are computationally expensive.

\subsubsection{Comparison of RegCM3 and MISR Summertime Aerosol Optical Depth}

[22] Further, comparisons of RegCM3's summertime AOD values to MISR's JJA estimates of AOD are completed. As seen prior in the annual figures, MISR's values over the entire region are significantly higher than RegCM3 DUST (Figure 7). This pattern is particularly noticeable over the valley of central Iraq. Table 2 lists JJA values for MISR as well as RegCM3 simulations. Here, MISR values range from 0.30 to 0.50 whereas DUST values are around 0.15 . More specifically, over Kuwait, JJA AOD DUST estimates are approximately 0.20 and underestimate MISR values by nearly $40 \%$. This trend is also seen over the boxed region where observations are nearly double RegCM3's simulated AOD. In fact, initial RegCM3 values lie outside one standard deviation of both MISR retrievals for Kuwait and the boxed region. As described prior, including representation for wind variability increases dust emissions across the entire domain. As a result, WIND simulation values for 
SRB JJA Sfc. SW Incident (W/m-2)

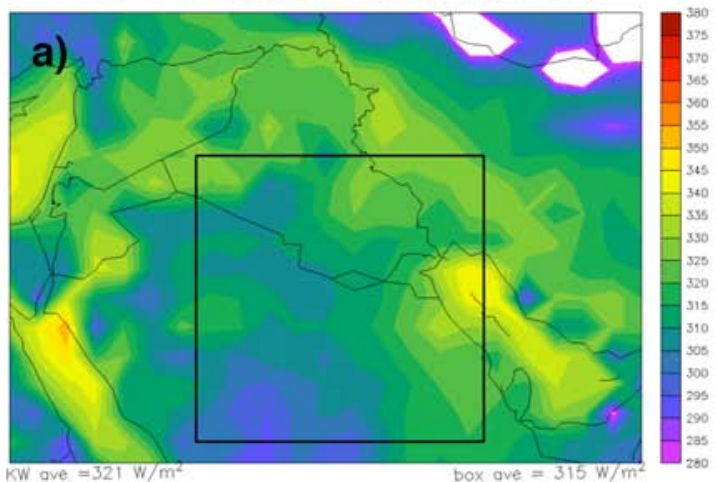

DUST JJA Sfc. SW Incident (W/m-2)

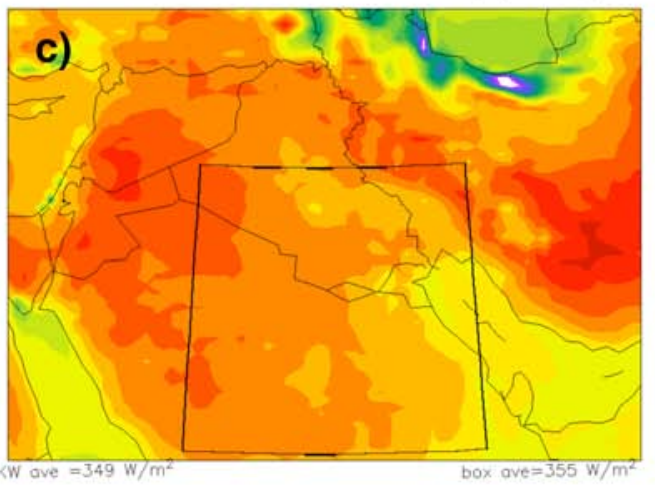

WIND-CONT JJA Sfc. SW Incident $(\mathrm{W} / \mathrm{m} \sim 2)$

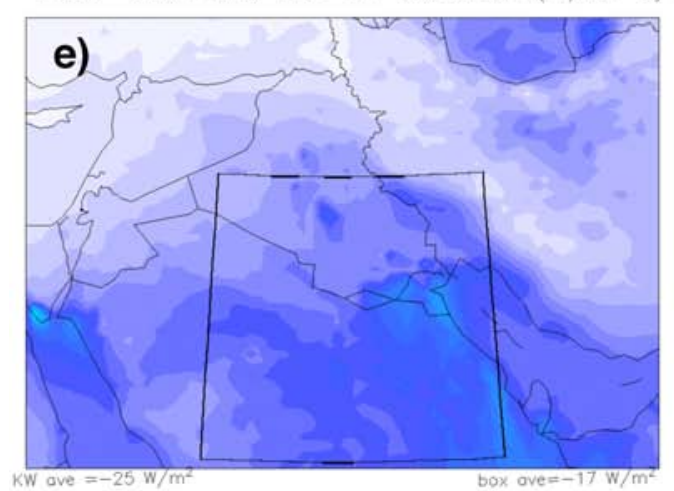

CONT JJA Sfc. SW Incident ( $\mathrm{W} / \mathrm{m} \sim 2)$

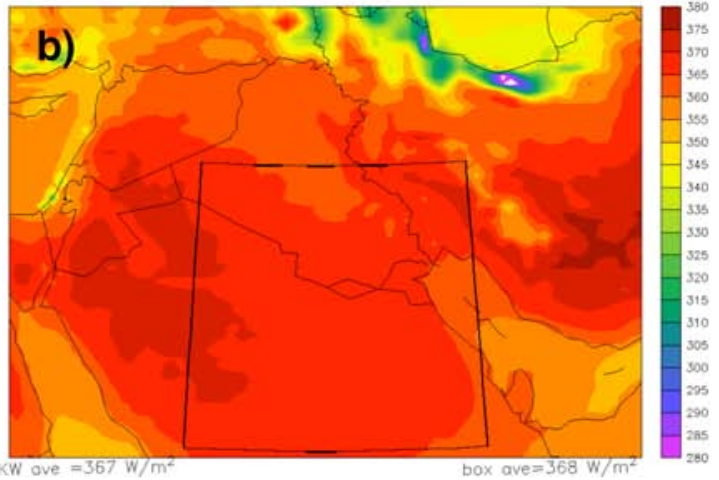

WIND JJA Sfc. SW Incident (W/m-2)

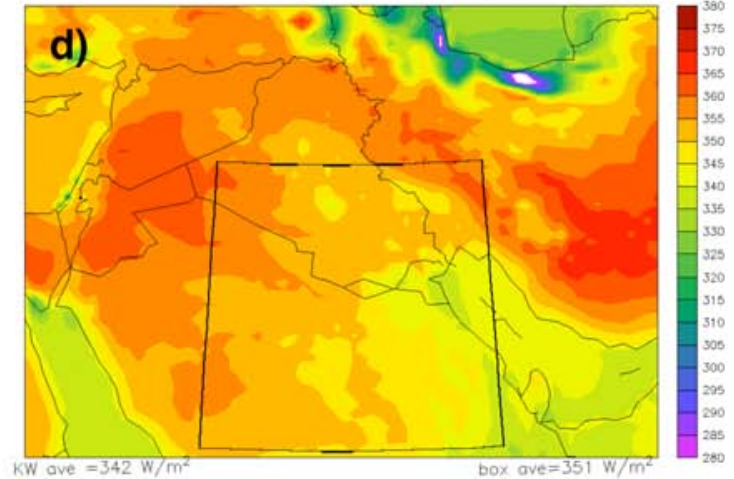

WIND-DUST JJA Sfc. SW Incident ( $\mathrm{W} / \mathrm{m}-2)$
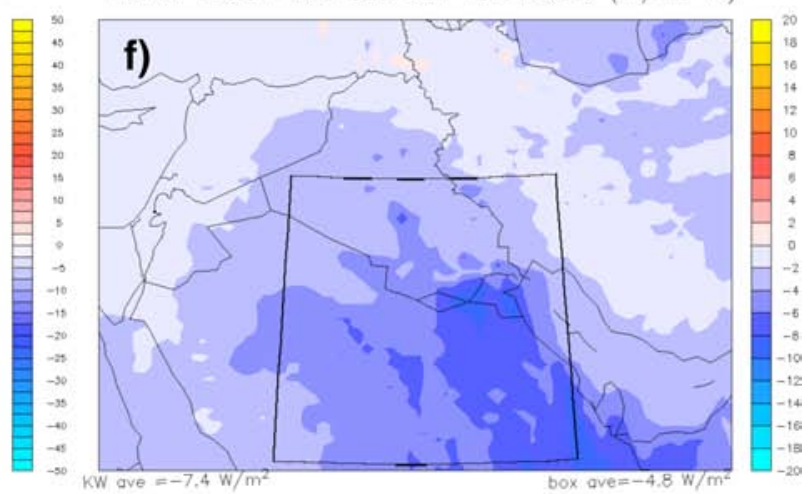

Figure 8. Average JJA monthly incident shortwave energy in (a) NASA-SRB, (b) CONT, (c) DUST, (d) WIND, (e) WIND-CONT, and (f) WIND-DUST for summers of 2000-2004. Note areal averages over both Kuwait and boxed region are also shown.

AOD more closely resemble MISR (see Figure 7). For example, along the Arabian Gulf Coast, WIND AOD values are now within 0.05 of MISR estimates. Over Kuwait, in WIND, the nearly $35 \%$ increase in dust emissions (compared to DUST) results in AOD values of 0.26 , which are within one standard deviation of MISR's AOD estimate at 0.35 (see Table 2). Nevertheless, with wind variability included, RegCM3 still underestimates dust emissions across most of the domain.

\subsection{Effects of Dust Emissions on Mean Summertime Climate}

[23] Since dust emissions of the WIND simulation are closer to observations, here we compare WIND results to a
RegCM3 simulation without the dust module implemented, CONT. Such a comparison will allow us to discern some of the effects of dust loading on the regional climate of southwest Asia.

\subsubsection{Surface Shortwave Incident Radiation}

[24] It is well known that as dust particulates are suspended into the atmosphere, incoming shortwave radiation is either scattered or absorbed depending on the particulate size [Tegen and Lacis, 1996; Miller and Tegen, 1998]. With RegCM3, it is possible to quantify theses effects on mean summertime incident shortwave radiation (SWI) over southwest Asia. First, using SRB estimates of SWI, we compare RegCM3's simulated values to observations (Figure 8). The attenuation of incident shortwave is plainly 
seen in Figure 8. Clearly visible is the large overestimation and fairly homogenous distribution of SWI values in RegCM3's CONT simulation. More specifically, RegCM3 estimates SWI values over most of the region close to $367 \mathrm{~W} / \mathrm{m}^{2}$, whereas SRB values are approximately $315 \mathrm{~W} / \mathrm{m}^{2}$ (see Figures $8 \mathrm{a}$ and $8 \mathrm{~b}$ ). However, including mineral aerosols in RegCM3 simulations does improve the model's ability to reproduce average SWI. For example, visible in Figure 8c, dust emissions cause reductions in SWI across Iraq, Iran, and Saudi Arabia. Over Kuwait, simulated SWI values $\left(349 \mathrm{~W} / \mathrm{m}^{2}\right)$ are now within $28 \mathrm{~W} / \mathrm{m}^{2}$ of observations. Likewise, the spatial distribution of SWI now more closely follows that of SRB, with maximum values over Jordan, western Saudi Arabia and the Zagros Mountains of western Iran. Likewise, including wind variability causes a further reduction of shortwave incident across the entire domain notably across Kuwait and coastal Saudi Arabia (Figure 8d). More specifically, additional attenuation of nearly $5-10 \mathrm{~W} / \mathrm{m}^{2}$ occurs over Kuwait and further south where AOD values increased by $0.05-0.10$ due to wind variability.

[25] The overall effect of dust emissions on surface shortwave can be seen in Figure 8e. Again, regions of significant dust loading in southern Iraq and Saudi Arabia see the largest reductions in average shortwave radiation reaching the surface (on the order of $20 \mathrm{~W} / \mathrm{m}^{2}$ ). Similar results are documented in the work of Zhang et al. [2009], where attenuation of surface shortwave radiation over East Asia due to mineral aerosols is between 10 to $25 \mathrm{~W} / \mathrm{m}^{2}$. The work of Konare et al. [2008] found larger decreases in surface shortwave radiation over West Africa (in some regions nearly $-90 \mathrm{~W} / \mathrm{m}^{2}$ ); however, significantly larger dust loading (AOD values closer to 1.0) are simulated by RegCM3 over West Africa. Nonetheless, RegCM3 still overestimates SWI by approximately $20-30 \mathrm{~W} / \mathrm{m}^{2}$ throughout the domain. Undoubtedly, some of this bias is due to the underestimation in dust over the region. Moreover, since cloud cover over this region in the summertime is nearly zero and modeled total column water vapor matches reanalysis data, it is believed that the radiative physics package within RegCM may not properly absorb radiation aloft as alluded to in the work of Zhang and Lin [1998]. In any case, further work is necessary in addressing this bias.

[26] As including wind variability increases dust emissions, a further decrease in surface shortwave radiation occurs across most of the domain (see Figure 8f). In particular, the increased dust loading over Kuwait and coastal Saudi Arabia causes further reduction in the incident shortwave radiation over this region. More specifically, the increased dust loading results in shortwave reductions from 340 to $330 \mathrm{~W} / \mathrm{m}^{2}$ over this region. As will be discussed, these decreases in surface energy fluxes have further effects on the summertime climate of southwest Asia.

\subsubsection{Summertime Two Meter Temperatures}

[27] Figure 9 displays the JJA mean daily surface temperatures for UDEL observations as well as RegCM3's CONT, DUST, and WIND simulations. From the cool, mountainous regions of Turkey and Iran in the north, to the warm desert regions of Iraq and Saudi Arabia in the south, RegCM3 does generally well in simulating the spatial distribution of temperature over the region. However, average simulated temperatures are approximately $1-4^{\circ} \mathrm{C}$ warmer than UDEL values across the entire Mesopotamian Valley stretching down the Arabian Peninsula (compare Figures 9a to $9 \mathrm{~b}$ ). As expected, including dust emissions impacts surface temperatures across the domain (Figure 9c). That is, with a substantial attenuation of incident shortwave radiation, average JJA temperatures over Kuwait drop by $0.5^{\circ} \mathrm{C}$ from 38.3 to $37.8^{\circ} \mathrm{C}$ and over the boxed region by $0.4^{\circ} \mathrm{C}$ (Figure 9d). In fact, as expected, cooling across the entire domain occurs when dust is introduced into the model (see Figure 9e). However, over regions of large dust loading, the effects on temperature are more profound; some areas of coastal Saudi Arabia experience average temperature cooling by nearly $1^{\circ} \mathrm{C}$. This reduction continues throughout most of the Arabian Gulf demonstrating the importance of including dust emissions in accurately simulating the mean summertime climate over the region. Results in this study are consistent with Zhang et al. [2009] where dust emissions cause surface cooling on the order of 0.5 to $1.0^{\circ} \mathrm{C}$. In another study, Konare et al. [2008], dust emissions caused more significant cooling (nearly $2^{\circ} \mathrm{C}$ ) over West Africa, but did not include the effects of dust on longwave energy. Hence, neglecting such feedback may result in too much cooling. Nevertheless, including wind variability has only a small effect on temperature over the region, particularly when compared to the overall effect of dust (Figure 9e) on cooling. That is, the increased dust emissions from wind variability results in about a tenth of a degree cooling (see Figure 9f).

[28] Given the large attenuation of shortwave radiation at the surface, one would perhaps expect a larger temperature reduction at the surface. However, it should be noted, again, that dust absorbs shortwave radiation as well as traps upwelling longwave radiation, depending on particle size [Tegen and Lacis, 1996]; consequently, dust causes some heating aloft in the dust layer [Miller and Tegen, 1998]. These processes are noticeable in RegCM3 and most likely help mute the cooling signal at the surface. As a result, average surface temperatures are still $1-2^{\circ} \mathrm{C}$ warmer over the boxed region and Kuwait. Likewise, although shortwave radiation reaching the surface decreases by nearly $25 \mathrm{~W} / \mathrm{m}^{2}$, the difference (or decrease) in the amount absorbed at the surface is less (by about 30\%) due to the large surface albedo over the region. This factor may explain why the increased shortwave incident attenuation caused by wind variability does not result in much cooling. Regardless, current work is being completed in addressing the residual warm bias of RegCM3; it is believed that surface albedo over desert regions in RegCM3 is significantly underestimated, resulting in excess shortwave absorption and hence excess warmth. However, further dust emissions would further cool the entire domain, particularly the Mesopotamian Valley of Iraq.

\section{Summary and Conclusions}

[29] Improvements over southwest Asia are made to a regional climate model's dust scheme by including modules that help quantify subgrid variability of certain surface features, namely wind speed and roughness length. Using model calculated values for average wind speed and the dry convective velocity scale, the probability of achieving a certain wind value is computed assuming wind speeds follow a normal distribution. The dust module's calculations 
UDEL $2 \mathrm{~m}$ JJA Temperature (C)

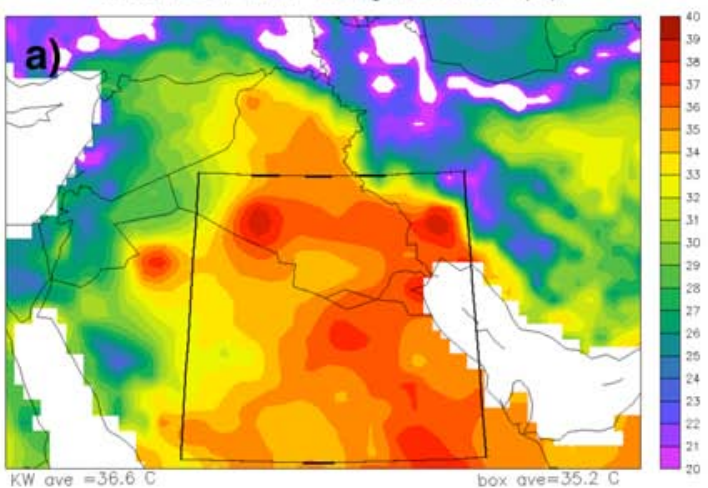

Dust 2m JJA Temperature (C)

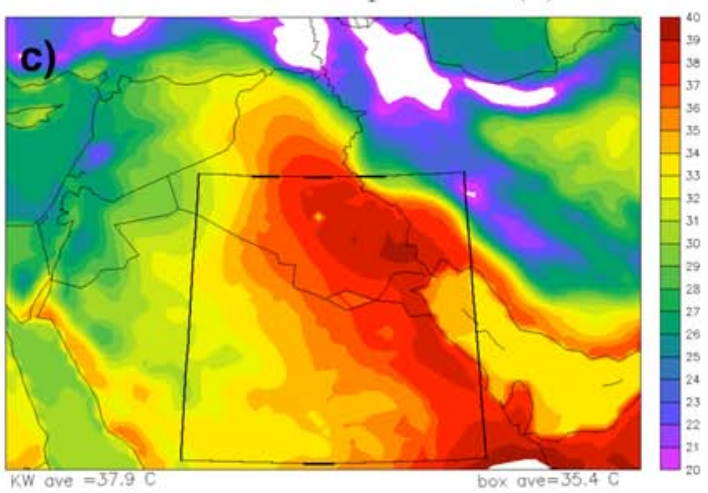

WIND-CONT 2m JJA Temperature (C)

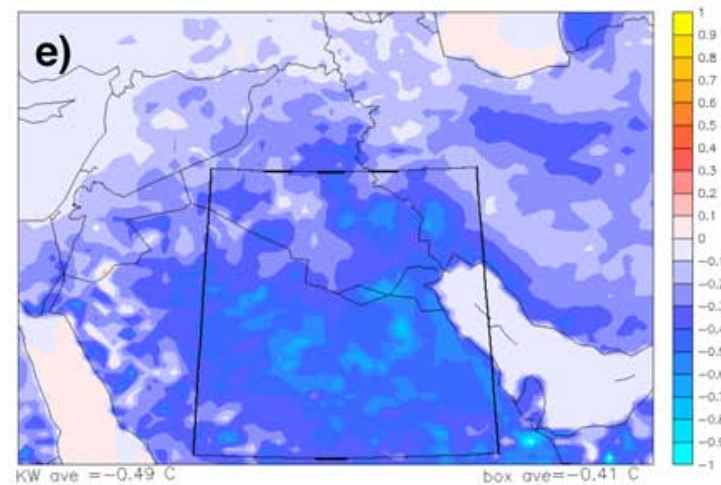

CONT 2m JJA Temperature (C)

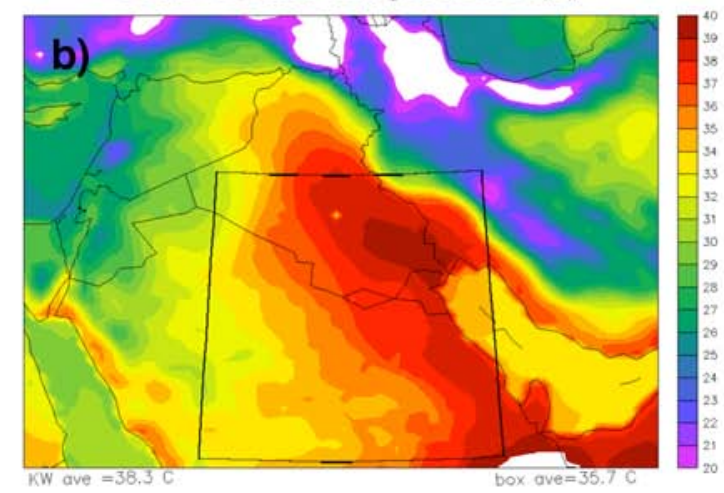

WIND $2 \mathrm{~m}$ JJA Temperature (C)

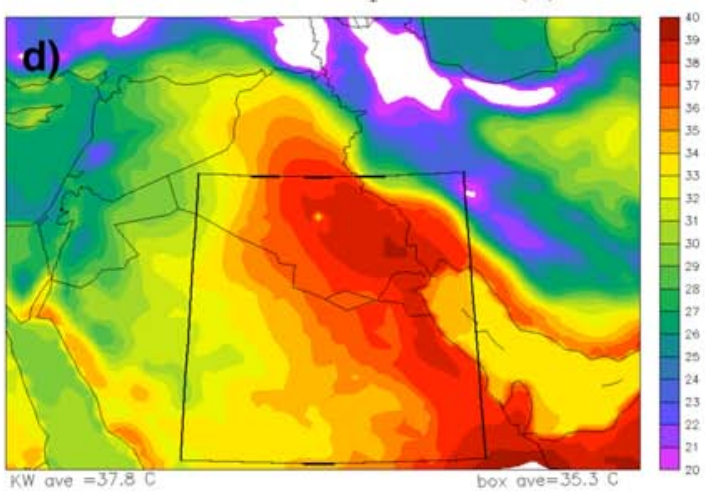

WIND-DUST $2 \mathrm{~m}$ JJA Temperature (C)

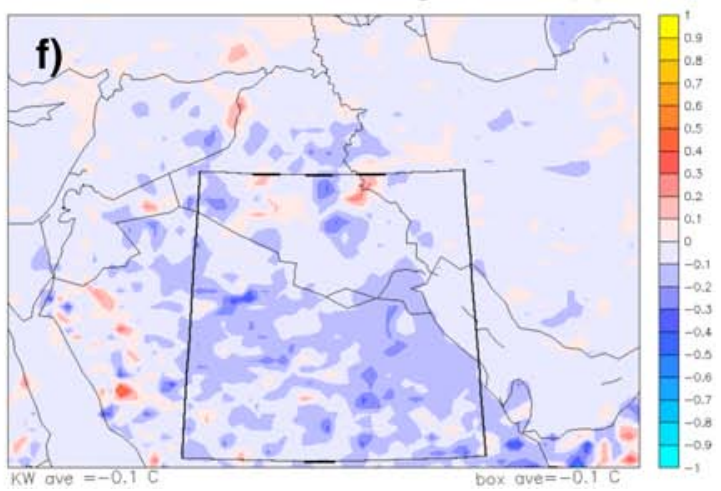

Figure 9. Monthly average summertime $2 \mathrm{~m}$ temperature (in Celsius) for (a) UDEL, (b) CONT, (c) DUST, (d) WIND, (e) WIND-CONT, and (f) WIND-DUST for the summers of 2000-2004. Also shown are the areal averages over both Kuwait and boxed region.

are then performed for all wind bin values and integrated based upon the corresponding probability. Results indicate that the dust model is quite sensitive to wind variability over this region as AOD values increase by nearly $40 \%$. Consequently, a once large underestimation in AOD values compared to MODIS and MISR estimations, is now reduced. It is important to note that other studies have examined the performance of this model over different regions with varying results [e.g., Zakey et al., 2006, 2009; Konare et al., 2008]. For example, while Zakey et al. [2006] did not find underestimations over West Africa, their study only examined one summer period (June, July, and August of 2000.) In fact, some underestimations in AOD were found over East Asia in the work of Zhang et al. [2009] as well as eastern Africa in the work of Konare et al. [2008]. Yet it is unclear whether industrial aerosols, poorly modeled transport of dust, or insufficient surface emissions contributes to these biases. Therefore, further testing of the wind variability model over other regions should be performed. Nevertheless, these results are similar to those of Morcrette et al. [2008] which found a $30 \%-40 \%$ increase in AOD from dust emissions caused by wind gustiness in the ECMWF model over the Arabian Peninsula. Lastly, the work of Cakmur et al. [2004] found more than a 50\% increase in summertime AOD over this region, but their results include multiple subgrid parameterizations for gustiness including moist convection and turbulent kinetic energy. Here, we examine only the effects of dry convection. 
[30] In any event, the additional dust emissions lead to further attenuation of shortwave incident by 5 to $10 \mathrm{~W} / \mathrm{m}^{2}$. However, additional temperature differences are negligible and on the order of $0.1^{\circ} \mathrm{C}-0.2^{\circ} \mathrm{C}$ (Figure 9f). Nevertheless, additional work in simulating the dust source of central Iraq needs to be completed; with this dust source properly initiated, the remaining AOD bias over the region should be eliminated resulting in further reductions in temperature and shortwave radiation biases. It is believed that the specified soil type over Iraq may curb dust saltation and ultimately dust emissions.

[31] In addition to subgrid wind variability, work is completed to represent the variability of land cover or roughness length over a grid cell. Here, an empirical distribution is calculated based on the USGS's GLCC 4 kilometer data set. Again, the dust model performs all calculations based on the corresponding roughness length value and the percent of the grid cell covered by that vegetation type (i.e., roughness length). Unlike wind variability, the dust module does not show a strong response to roughness length variability over southwest Asia. This result is most likely due to the fairly homogeneous land cover over the Arabian Peninsula. It is expected that over regions like the Sahel of West Africa, where land cover varies greatly, such a scheme may have more significant effects on dust loading.

[32] Given the new model including subgrid wind variability, analysis is completed in quantifying the effects of dust emissions on the summertime surface climate of southwest Asia. Model results indicate that dust events over this region have significant impacts on both surface shortwave radiation and temperature. More specifically, average temperatures over the Arabian Peninsula cool between 0.5 and $0.75^{\circ} \mathrm{C}$ while shortwave incident energy decreases between 20 and $30 \mathrm{~W} / \mathrm{m}^{2}$. Yet, RegCM3 still simulates a significant warm temperature bias and excessive incoming shortwave radiation bias. Current work is addressing both of these biases. Future work should examine RegCM3's performance in modeling year to year fluctuations in temperature and shortwave energy as well as the effects of dust on this variability. In addition, work in addressing how the lateral boundaries are represented should also be completed. That is, preliminary results indicate that representing dust at the boundaries (dust boundary conditions) significantly affects dust concentrations and subsequently aerosol optical depth in the domain. Nevertheless, this work demonstrates the importance of dust emissions in shaping the summertime climate over southwest Asia. Therefore, to simulate accurately the summertime climate of this region, it is necessary to include dust emissions with representation for the variability of wind speed at the subgrid scale.

[33] Acknowledgments. The authors are grateful to all members of the Eltahir group and M.I.T. Parsons Laboratory that contributed in some way to this work. This work has been funded through support by the Kuwait Foundation for the Advancement of Science.

\section{References}

Abdou, W. A., D. A. Diner, J. V. Martonchik, C. J. Bruegge, R. A. Kahn, B. J. Gaitley, K. A. Crean, L. A. Remer, and B. Holben (2005), Comparison of coincident multiangle imaging spectroradiometer and moderate resolution imaging spectroradiometer aerosol optical depths over land and ocean scenes containing aerosol robotic network sites, J. Geophys. Res., 110, D10S07, doi:10.1029/2004JD004693.

Alfaro, S., and L. Gomes (2001), Modelling mineral aerosol production by wind erosion: Emission intensities and aerosol size distributions in source areas, J. Geophys. Res., 106(D16), 18,075-18,084, doi:10.1029/ 2000JD900339.

Cakmur, R. V., R. L. Miller, and O. Torres (2004), Incorporating the effect of small-scale circulations upon dust emission in an atmospheric general circulation model, J. Geophys. Res., 109, D07201, doi:10.1029/ 2003JD004067.

Darnell, W., W. Staylor, N. A. Ritchey, S. K. Gupta, and A. C. Wilber (1996), Surface radiation budget: A long-term global data set of shortwave and longwave fluxes, Eos Trans. $A G U, 77,86$. (Available at http://www.agu.org/eos_elec/95206e.html)

Davies, H., and R. Turner (1977), Updating prediction models by dynamical relaxation: An examination of the technique, Q.J.R. Meteorol. Soc., 103(436), 225-245.

Deardorff, J. W. (1974), Three-dimensional numerical study of turbulence in an entraining mixed layer, Boundary Layer Meteorol., 7, 199-226.

Dickinson, R., A. Henderson-Sellers, and P. Kennedy (1993), Biosphere Atmosphere Transfer Scheme (BATS) version 1e as coupled to the NCAR Community Climate Model, NCAR Tech. Rep. TN-387+STR, p. 72, Natl. Cent. for Atmos. Res., Boulder, Colo.

Engelstaedter, S., and R. Washington (2007), Temporal controls on global dust emissions: The role of surface gustiness, Geophys. Res. Lett., 34, L15805, doi:10.1029/2007GL029971.

Giorgi, F., M. Marinucci, and G. Bates (1993a), Development of a second generation regional climate model $(\mathrm{regcm} 2)$ : Part I. Boundary layer and radiative transfer processes, Mon. Weather Rev., 121, 2794-2813.

Giorgi, F., M. Marinucci, G. Bates, and G. DeCanio (1993b), Development of a second generation regional climate model (regcm2): Part II. Convective processes and assimilation of lateral boundary conditions, Mon Weather Rev., 121, 2814-2832.

Giorgi, F., L. Mearns, C. Shields, and L. McDaniel (1998), Regional nested model simulations of present day and 2 xco 2 climate over the Central Plains of the U.S, Clim. Change, 40, 457-493.

Grell, G., J. J. Dudhia, and D. Stauffer (1994), A description of the fifthgeneration Penn State/NCAR Mesoscale Model (MM5), Tech. Note NCAR/TN-398+STR, Natl. Cent. for Atmos. Res., Boulder, Colo.

Gupta, S. K., N. A. Ritchey, A. C. Wilber, C. H. Whitlock, G. G. Gibson, and P. W. Stackhouse Jr. (1999), A climatology of surface radiation budget derived from satellite data, J. Clim., 12(8), 2691-2710.

Holben, B. N., et al. (1998), Aeronet-A federal instrument network and data archive for aerosol characterization, Remote Sens. Environ., 66, $1-16$

Holtslag, A., E. de Bruin, and H. Pan (1990), A high-resolution air mass transformation model for short-range weather forecasting, Mon. Weather Rev., 118, 1561-1575.

Kalnay, E., et al. (1996), The NCEP/NCAR 40-year reanalysis project, Bull. Am. Meteorol. Soc., 77(3), 437-471.

Kaufman, Y. J., D. Tanre, L. A. Remer, E. Vermote, A. Chu, and B. N. Holben (1997), Operational remote sensing of tropospheric aerosol over land from EOS moderate resolution imaging spectroradiometer, J. Geophys. Res., 102(D14), 17,051-17,067, doi:10.1029/96JD03988.

Kiehl, J., J. Hack, G. Bonan, B. Boville, B. Breigleb, D. Williamson, and P. J. Rasch (1996), Description of the NCAR Community Climate Model (ccm3), Tech. Note NCAR/TN-420+STR, Natl. Cent. for Atmos. Res., Boulder, Colo.

Konare, A., A. S. Zakey, F. Solmon, F. Giorgi, S. Rauscher, S. Ibrah, and X. Bi (2008), A regional climate modeling study of the effect of desert dust on the West African monsoon, J. Geophys. Res., 113, D12206, doi:10.1029/2007JD009322.

Laruent, B., B. Marticorena, G. Bergametti, J. Leon, and N. Mahowald (2008), Modeling mineral dust emissions from the Sahara desert using new surface properties and soil database, J. Geophys. Res., 113, D14218, doi:10.1029/2007JD009484.

Legates, D. R., and C. J. Willmott (1990), Mean seasonal and spatial variability global surface air temperature, Theor. Appl. Climatol., 41, 11-21.

Lunt, D. J., and P. Valdes (2002), The modern dust cycle: Comparison of model results with observations and study of sensitivities, J. Geophys. Res., 107(D23), 4669, doi:10.1029/2002JD002316.

Marcella, M. P., and E. A. B. Eltahir (2008), Modeling the hydroclimatology of Kuwait: The role of subcloud evaporation in semiarid climates, J. Clim., 21, 2976-2989.

Marticorena, B., and G. Bergametti (1995), Modeling the atmospheric dust cycle: 1. design of soil-derived dust emission scheme, J. Geophys. Res., 100(D8), 16,416-16,430, doi:10.1029/95JD00690.

Martonchik, J. V., D. J. Diner, R. Kahn, B. Gaitley, and B. N. Holben (2004), Comparison of MISR and AERONET aerosol optical depths over 
desert sites, Geophys. Res. Lett., 31, L16102, doi:10.1029/ 2004GL019807.

Martonchik, J. V., D. J. Diner, R. A. Kahn, T. P. Ackerman, M. M. Verstraete, B. Pinty, and H. R. Gordon (1998), Techniques for the retrieval of aerosol properties over land and ocean using multiangle imaging, IEEE Trans. Geosci. Remote Sens., 35, 1212-1227.

Miller, M. J., A. C. M. Beljaars, and T. N. Palmer (1992), The sensitivity of the ecmwf model to the parameterization of evaporation from the tropical oceans, J. Clim., 5, 418-434.

Miller, R., and I. Tegen (1998), Climate response to soil dust aerosols, J. Clim., 11, 3247-3267.

Mohalfi, S., H. Bedi, T. N. Krishnamurti, and S. D. Cocke (1998), Impact of shortwave radiative effects of dust aerosols on the summer season heat low over Saudi Arabia, Mon. Weather Rev., 126, 3153-3168.

Morcrette, J.-J., A. Beljaars, A. Benedetti, L. Jones, and O. Boucher (2008), Sea-salt and dust aerosols in the ECMWF IFS model, Geophys. Res. Lett., 35, L24813, doi:10.1029/2008GL036041.

Pal, J., E. Small, and E. A. B. Eltahir (2000), Simulation of regional scale water and energy budgets: Representation of subgrid cloud and precipitation processes within RegCM, J. Geophys. Res., 105(D24), 29,579-29,594, doi:10.1029/2000JD900415.

Pal, J., et al. (2007), Regional climate modeling for the developing world: The ICTP RegCNET and RegCM, Bull. Am. Meteorol. Soc., 88, 1395-1409.

Prasad, A. K., and R. P. Singh (2006), Comparison of misr-modi aerosol optical depth over the indo-gangetic basin during the winter and summer seasons (200-2005), Remote Sens. Environ., 107, 109-119.

Prospero, J. M., P. Ginoux, O. Torres, E. Nicholson, and T. E. Gill (2002), Environmental characterization of global sources of atmospheric soil dust identified with the Nimbus 7 total ozone mapping spectrometer (TOMS) absorbing aerosol product, Rev. Geophys., 40(1), 1002, doi:10.1029/ 2000RG000095.

Reynolds, R. W. (2002), An improved in situ and satellite SST analysis for climate, J. Clim., 15(13), 1609-1625.

Schulz, M., Y. J. Balkanski, W. Guelle, and F. Dulac (1998), Role of aerosol size distribution and source location in a three-dimensional simulation of a Saharan dust episode tested against satellite-derived optical thickness, J. Geophys. Res., 103(D9), 10,579-10,592, doi:10.1029 97JD02779.
Sokolik, I. N., D. M. Winker, G. Bergametti, D. A. Gillette, G. Carmichael, Y. J. Kaufman, L. Gomes, L. Schuetz, and J. E. Penner (2001), Introduction to special section: Outstanding problems in quantifying the radiative impacts of mineral dust, J. Geophys. Res., 106(D16), 18,015-18,027, doi:10.1029/2000JD900498.

Solmon, F., M. Mallet, N. Elguindi, F. Giorgi, A. S. Zakey, and A. Konare (2008), Dust aerosol impact on regional precipitation over western Africa, mechanisms and sensitivity to absorption properties, Geophys. Res. Lett., 35, L24705, doi:10.1029/2008GL035900.

Tegen, I., and A. A. Lacis (1996), Modeling of particle size distribution and its influence on the radiative properties of mineral dust aerosols, J. Geophys. Res., 101(D14), 19,237-19,244, doi:10.1029/95JD03610.

U.S. Geological Survey (USGS) (1997), Global Land Cover Characterization, Reston, Va. (Available at http://edcsns17.cr.usgs.gov/glcc/)

Willis, G. E., and J. W. Deardorff (1974), A laboratory model of the unstable planetary boundary layer, J. Atmos. Sci., 31, 1297-1307.

Willmott, C. J., and K. Matsuura (1995), Smart interpolation of annually averaged air temperature in the United States, J. Appl. Meteorol., 34, 2577-2586.

Wyngaard, J. C. (1985), Structure of the planetary boundary layer and implications for its modeling. J. Clim. Appl. Meteorol., 24, 1131-1142.

Zakey, A., F. Solmon, and F. Giorgi (2006), Implementation and testing of a desert dust module in a regional implementation and testing of a desert dust module in a regional climate model, Atmos. Chem. Phys., 6 , 4687-4704.

Zeng, X., M. Zhao, and R. Dickinson (1998), Intercomparison of bulk aerodynamic algorithms for the computation of sea surface fluxes using TOGA coare and TAO data, J. Clim., 11, 2628-2644.

Zhang, D. F., A. S. Zakey, X. J. Gao, F. Giorgi, and F. Solmon (2009) Simulation of dust aerosol and its regional feedbacks over East Asia using a regional climate model, Atmos. Chem. Phys., 9, 1095-1110.

Zhang, M., and W. Y. Lin (1998), Bias of atmospheric shortwave absorption in the NCAR Community Climate Models 2 and 3: Comparison with monthly GEBA/ERBE measurements, J. Geophys. Res., 103(D8), 8919-8925, doi:10.1029/98JD00343.

E. A. B. Eltahir and M. P. Marcella, Department of Civil and Environmental Engineering, Massachusetts Institute of Technology, Cambridge, MA 02139, USA. (marcpace@mit.edu) 